\title{
Purines inhibit the development of mouse embryos in vitro*
}

\author{
Aida Nureddin $\dagger$, Eileen Epsaroß and Ann A. Kiessling†‡ \\ $\dagger$ Department of Obstetrics, Gynecology and Reproductive Biology, and $\ddagger$ Laboratory for Human \\ Reproduction and Reproductive Biology, Harvard Medical School, Seeley G. Mudd Building, \\ 250 Longwood Ave, Boston, MA 02115, USA
}

\begin{abstract}
Summary. The first cleavage of embryos derived from random-bred, inbred, and hybrid-inbred female mice was not arrested by purines at concentrations as high as $30 \mu \mathrm{M}$. Development after the first or second cleavage was arrested by hypoxanthine, adenosine or inosine, but not guanosine. In agreement with previous results, the purine-induced block was reversed when arrested embryos were transferred to purinefree media after $24 \mathrm{~h}$ in culture. The cleavage arrest was not due to elevations of cAMP as a result of inhibition of phosphodiesterase activity since similar concentrations of phosphodiesterase inhibitors or dibutyryl cAMP did not block development. Treatment with inhibitors of enzymes that convert IMP to AMP or to GMP did not reverse the hypoxanthine-induced block, thus demonstrating that mitotic arrest is mediated by a mechanism different from the hypoxanthine arrest of meiosis. Thymidine incorporation studies showed that the block did not prevent the onset of DNA synthesis. The results reveal a profound sensitivity to purine inhibition of a cell process that occurs during the first $30 \mathrm{~h}$ of mouse embryo development and is necessary for progession through the G2 or M phases of the second or third cleavage.
\end{abstract}

Keywords: purines; embryos; development; 2-cell block; mouse

\section{Introduction}

Hypoxanthine is a purine derived from the deribosylation of inosine and is a normal component of human serum. Concentrations similar to those found in serum are included in some culture media designed to support serum-free cell growth in vitro, such as Ham's F-10 medium (Ham, 1962). Hypoxanthine blocked the development of some strains of mouse embryos undergoing culture from the early 2-cell stage (Loutradis et al., 1987). Embryos from random-bred (CD1) females, but not hybrid-inbred (B6D2F1) females, were arrested from further cleavage in the presence of as little as $6 \mu$ M-hypoxanthine. The development block was reversible, however, since embryos transferred into hypoxanthine-free medium resumed development.

The profound, reversible effect of hypoxanthine on the development of mouse 2-cell embryos is of interest for several reasons, one of which is the possibility of a relationship with the previously reported 'two-cell block' of some mouse embryos (Biggers, 1971; Muggleton-Harris et al., 1982; Pratt \& Muggleton-Harris, 1988). Both phenomena are determined by the genotype of the oocyte and not that of the fertilizing spermatozoon (Muggleton-Harris et al., 1982; Loutradis et al., 1987; Pratt \& Muggleton-Harris, 1988). Moreover, strains reported to exhibit a block at the 2-cell stage only do so in our culture conditions if hypoxanthine is present (Loutradis et al., 1987; Jackson \& Kiessling, 1989; Fissore et al., 1989). Therefore, although the 'two-cell block' may be unrelated to the hypoxanthine sensitivity, it is also possible that suboptimal culture conditions inhibit the same sensitive, critical cell function that is inhibited by hypoxanthine.

\footnotetext{
*Reprint requests to Dr A. Kiessling, Harvard Medical School, Faulkner Hospital, 1153 Centre St, Boston, MA 02130 , USA

§resent address: Department of Biology, Lehigh University, Bethlehem, PA 18105, USA.
} 
In addition, hypoxanthine has been shown to play a significant role in the maintenance of meiotic arrest in vivo and in vitro (Downs et al., 1985, 1986; Eppig \& Downs, 1987; Downs \& Eppig, 1987). A mechanism proposed for the hypoxanthine-induced inhibition of meiosis is elevation of oocyte cAMP levels secondary to inhibition of phosphodiesterase (Chasin \& Harris, 1976; Downs et al., 1989). Reversal of the block by specific inhibitors of purine metabolizing enzymes indicate that guanosine and/or xanthine, possible metabolites of hypoxanthine, play a major role in the mechanism controlling germinal vesicle breakdown (Downs et al., 1986; Downs \& Eppig, 1987), in keeping with their effectiveness in inhibiting oocyte phosphodiesterase activity (Downs et al., 1989). A similar mechanism blocking the onset of mitosis could be operational during the initial cleavages of the mouse embryo, although the three orders of magnitude difference in effective concentrations of hypoxanthine $(6 \mu \mathrm{M}$ to block embryo cleavage versus $3-5 \mathrm{~mm}$ to block germinal vesicle breakdown) indicates that the mechanisms are different.

Purine metabolism is a complex scheme of interelated and reversible enzyme reactions involving ribosylations, phosphorylations and ring modifications, which are described as basically two pathways: the purine salvage pathway and the de-novo synthesis pathway. In the de-novo synthesis pathway, guanosine monophosphate (GMP) and adenosine monophosphate (AMP) arise from modifications of inosine monophosphate (IMP). Each conversion is a two-step reaction catalysed by separate enzymes as shown in Fig. 1. An increased concentration of hypoxanthine could result in an increase in IMP via the purine salvage pathway (reaction 3, Fig. 1) and a consequent elevation of GMP and/or AMP that could result in inhibition of mitosis as well as meiosis.

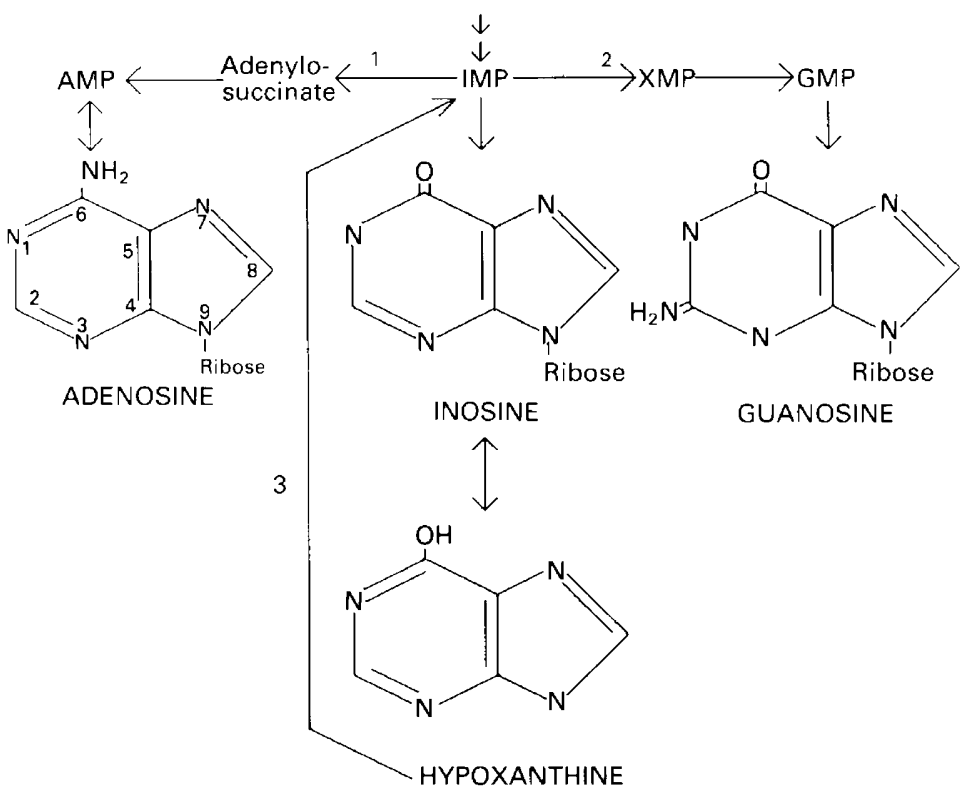

Fig. 1. Diagram of purine synthesis pathways. Reaction 1 is catalysed by adenylosuccinate synthetase (EC 6.3.4.4), Reaction 2 by IMP-dehydrogenase (EC 1.2.1.14) and Reaction 3 by hypoxanthine guanosine phosphoribosyl transferase (EC 2.4.2.8).

The work reported here was undertaken to identify the possible pathways involved in the hypoxanthine-induced cleavage arrest. We first studied the effects of hypoxanthine and other purines on pronuclear-stage embryos from random-bred, inbred and F1 hybrid-inbred mice to determine whether the initial cleavage was also reversibly blocked. We then investigated the possibility that hypoxanthine was inhibiting phosphodiesterase activity in the early embryo by mechanisms analogous to germinal vesicle maintenance (Downs et al., 1986; Downs et al., 
1989). And finally, we determined whether the block to cleavage also blocked the onset of DNA synthesis.

\section{Materials and Methods}

Animals and chemicals. Mouse strains were random bred Swiss and albino (CD1 and CFI respectively, Charles River, Wilmington, MA, USA); inbred SWR, C3H and DBA; and hybrid-inbred B6D2F1 (C57BL/6 $\times$ DBA), C3D2F1 $(\mathrm{C} 3 \mathrm{H} \times \mathrm{DBA})$ and B6SJL (C57BL/6 $\times$ SJL) (Jackson Labs, Bar Harbor, ME, USA). Females of each strain, 5-10 weeks old, were superovulated with intraperitoneal injections of 5 i.u. PMSG (Sigma Chemical Co., St. Louis, MO. USA) followed $48 \mathrm{~h}$ later by 5 i.u. hCG (Sigma). They were mated individually with B6D2F1 males and checked for copulation plugs $16-18 \mathrm{~h}$ after hCG injection, as described by Loutradis et al. (1987).

All purines, mycophenolic acid and bredinin were purchased from Sigma Chemical Co. Hadacidin was a generous gift of Merck, Sharpe and Dohme (Rahway, NJ, USA). All compounds were dissolved in Type I water (College of American Pathologists, Reagent Water Specifications, 1984), at least 100-fold the concentration to be tested in culture, and filter sterilized. Hypoxanthine and guanosine were dissolved by heating to $70^{\circ} \mathrm{C}$ for $1 \mathrm{~min}$ and then placing on a rotary shaker for $30-60 \mathrm{~min}$ with shaking. The sterile purine solutions were stored at room temperature.

Embryo and oocyte collection. Pronuclear embryos were collected $20-22 \mathrm{~h}$ after hCG in Dulbecco's phosphatebuffered saline (DPBS, Grand Island Biological Co., Grand Island, NY, USA) supplemented with $4 \mathrm{mg}$ bovine serum albumin/mi (BSA, Fraction V; Sigma) essentially as previously described (Loutradis et al., 1987; Jackson \& Kiessling, 1989). The embryos were then treated with 67 IU hyaluronidase/ml (Type V, $1300 \mathrm{NF}$ units-mg; Sigma) to disperse cumulus and granulosa cells. Germinal vesicle stage oocytes were collected from antral follicles in the ovaries of mice injected with 5 i.u. PMSG and killed $44 \mathrm{~h}$ later.

Embryo culture. Oocytes and embryos were cultured essentially as described by Jackson \& Kiessling (1989). Culture medium (modified Earle's balanced salt solution, EBSS, Sigma) was prepared using Type I (18 $\Omega$ ) water and filter sterilized. Briefly, groups of 12-20 zygotes, selected for the presence of two polar bodies and/or two pronuclei, were placed in the centre wells of organ culture dishes (Falcon No. 3037, Becton Dickinson \& Co., Cockeysville, MD, USA) containing $1 \mathrm{ml}$ EBSS supplemented with $4 \mathrm{mg} \mathrm{BSA} / \mathrm{ml}, 10 \mu \mathrm{M}$-ethylenediamine tetraacetic acid (EDTA, Sigma) and the compounds to be tested as described in the text. The media were overlayed with $1 \mathrm{ml}$ washed oil (Silicone oil, Aldrich Chemical Co., Milwaukee, WI, USA). All culture conditions were pre-equilibrated overnight; incubation was at $37^{\circ} \mathrm{C}, 7-8 \% \mathrm{CO}_{2}$ in air $(\mathrm{pH}=7 \cdot 1-7 \cdot 3)$. Cleavage to 2 cells was scored at $24 \mathrm{~h}$ of culture; development to morulae (taken as all morulae plus blastocysts) and blastocysts was assessed at $96 \mathrm{~h}$ of culture and expressed as percentages of the number of 2-cell embryos. Morulae were defined as compacted embryos with 8 cells or more, and embryos were scored as blastocysts from the early cavitating stage.

Germinal vesicle-stage oocytes surrounded by a layer of granulosa cells were cultured in groups of 20 for $24 \mathrm{~h}$ as described in the text. Following culture, the presence of germinal vesicles and/or polar bodies was determined microscopically at a magnification of $\times 100$.

DNA synthesis was assessed by autoradiography (Clarke \& Masui, 1983) of embryos cultured for $12-15 \mathrm{~h}$ in $6 \mu \mathrm{Ci}$ $\left[{ }^{3} \mathrm{H}\right]$ thymidine $/ \mathrm{ml}$ (sp. act. $84 \mathrm{Ci} / \mathrm{mmol}$ : New England Nuclear, DuPont, Boston, MA, USA). The labelled nucleoside was added to culture's containing 15-20 embryos at the mid-pronuclear stage ( $30 \mathrm{~h}$ after hCG) or at the late 2-cell stage $(40 \mathrm{~h}$ after $\mathrm{hCG})$ in either the absence or presence of $30 \mu \mathrm{m}$-hypoxanthine. Parallel cultures with no radiolabel were maintained as controls. The experiment was replicated three times yielding a minimum of 40 embryos from each group for examination by autoradiography. Thymidine incorporation was assessed by the presence of silver grains over embryonic nuclei (Clarke \& Masui, 1983).

Statistics. Student's $t$ test was used for statistical analyses of the data.

\section{Results}

\section{Embryo development in hypoxanthine}

Exposure of zygotes from all strains examined to $30 \mu \mathrm{m}$-hypoxanthine $20-22 \mathrm{~h}$ after hCG did not inhibit the initial cleavage (Table 1). Thereafter, more than $75 \%$ of the embryos from CD1, $\mathrm{CF} 1, \mathrm{SWR}, \mathrm{C} 3 \mathrm{H}$ and $\mathrm{C} 3 \mathrm{D} 2 \mathrm{~F} 1$ females arrested after the first or second cleavage (Tables 1 and 2). Embryos from C57BL/6 and DBA females were less sensitive to hypoxanthine: $62 \%$ and $43 \%$, respectively, of those that cleaved to 2 cells also developed to morulae (Table 1). The most hypoxanthine-resistant zygotes ( $74 \%$ to morulae) were recovered from females of the F1 hybrid of these strains, B6D2F1. In contrast, development to morulae of zygotes from the other hybrid strain of DBA, C3D2F1, was significantly $(P<0.05)$ inhibited by the presence of hypoxanthine 
(Table 1). Zygotes from 5 of the 9 strains examined were therefore sensitive to hypoxanthine; embryos from C57BL/6, DBA, their F1 hybrid, B6D2F1, and another F1 hybrid of C57BL/6, B6SJL, were the most resistant of those tested.

Table 1. Effect of hypoxanthine on mouse embryo development in vitro

\begin{tabular}{|c|c|c|c|c|}
\hline \multirow{2}{*}{$\begin{array}{l}\text { Dam } \\
\text { Strain }\end{array}$} & \multirow[b]{2}{*}{ Hypoxanthinet } & \multicolumn{3}{|c|}{ Development* } \\
\hline & & Two-cell + & Morulae§ & Blastocysts§ \\
\hline \multicolumn{5}{|c|}{ Random-bred } \\
\hline CDl & $\begin{array}{l}-(4) \\
+(4)\end{array}$ & $\begin{array}{l}90 \pm 4 \\
90 \pm 4\end{array}$ & $\begin{array}{l}91 \pm 1 \\
17 \pm 4\end{array}$ & $\begin{array}{r}76 \pm 6 \\
6 \pm 4\end{array}$ \\
\hline \multicolumn{5}{|l|}{ Inbred } \\
\hline SWR & $\begin{array}{l}-(3) \\
+(3)\end{array}$ & $\begin{array}{l}91 \pm 5 \\
90 \pm 2\end{array}$ & $\begin{array}{r}90 \pm 2 \\
7 \pm 4\end{array}$ & $\begin{array}{r}76 \pm 10 \\
2 \pm 2\end{array}$ \\
\hline $\mathrm{C} 3 \mathrm{H}$ & $\begin{array}{l}-(4) \\
+(5)\end{array}$ & $\begin{array}{l}83 \pm 9 \\
82 \pm 8\end{array}$ & $\begin{array}{l}84 \pm 7 \\
13 \pm 4\end{array}$ & $\begin{array}{l}77 \pm 9 \\
11 \pm 3\end{array}$ \\
\hline DBA & $\begin{array}{l}-(6) \\
+(7)\end{array}$ & $\begin{array}{l}89 \pm 6 \\
86 \pm 6\end{array}$ & $\begin{array}{l}67 \pm 7 \\
43 \pm 12^{*}\end{array}$ & $\begin{array}{r}15 \pm 5 \\
4 \pm 2\end{array}$ \\
\hline C57BL/6 & $\begin{array}{l}-(6) \\
+(5)\end{array}$ & $\begin{array}{l}81 \pm 5 \\
83 \pm 4\end{array}$ & $\begin{array}{l}86 \pm 5 \\
62 \pm 5^{*}\end{array}$ & $\begin{array}{l}84 \pm 4 \\
55 \pm 6\end{array}$ \\
\hline \multicolumn{5}{|c|}{ Hybrid-inbred } \\
\hline B6D2Fl & $\begin{array}{l}-(2) \\
+(2)\end{array}$ & $\begin{array}{l}85 \pm 16 \\
82 \pm 9\end{array}$ & $\begin{array}{l}96 \pm 4 \\
74 \pm 14^{*}\end{array}$ & $\begin{array}{l}96 \pm 4 \\
69 \pm 19\end{array}$ \\
\hline C3D2F1 & $\begin{array}{l}-(4) \\
+(4)\end{array}$ & $\begin{array}{l}92 \pm 3 \\
92 \pm 2\end{array}$ & $\begin{array}{l}69 \pm 6 \\
23 \pm 5\end{array}$ & $\begin{array}{l}57 \pm 11 \\
15 \pm 8\end{array}$ \\
\hline B6SJL & $\begin{array}{l}-(2) \\
+(2)\end{array}$ & $\begin{array}{l}91 \pm 4 \\
93 \pm 7\end{array}$ & $\begin{array}{l}91 \pm 10 \\
83 \pm 10^{*}\end{array}$ & $\begin{array}{l}91 \pm 10 \\
83 \pm 10\end{array}$ \\
\hline
\end{tabular}

*Development to morulae was not significantly $(P \geq 0.05)$ depressed in the presence of hypoxanthine.

†Number in parentheses is number of replicates, each of which consisted of 12-20 embryos from a pool of 2-3 females, as described in 'Materials and Methods'.

$\ddagger \% \pm$ Standard errors of the mean of pronuclear embryos. There were no significant differences $(P>0.05)$ in development to 2 -cells between zygotes cultured with or without hypoxanthine.

$\S \%$ of the mean of 2 -cell stages.

Table 2. Purine inhibition of mouse embryo development

\begin{tabular}{|c|c|c|c|c|}
\hline \multirow{2}{*}{$\begin{array}{l}\text { Dam } \\
\text { strain }\end{array}$} & \multirow{2}{*}{$\begin{array}{l}\text { Purinet } \\
(30 \mu \mathrm{M})\end{array}$} & \multicolumn{3}{|c|}{ Development } \\
\hline & & Two-cells & Morulae & Blastocysts \\
\hline \multirow[t]{7}{*}{ CDI } & None (5) & $79 \pm 1$ & $83 \pm 5$ & $66 \pm 5$ \\
\hline & Hypoxanthine (5) & $91 \pm 4$ & $4 \pm 2$ & $3 \pm 2$ \\
\hline & Adenosine (4) & $72 \pm 12$ & $19 \pm 8$ & $9 \pm 5$ \\
\hline & Inosine (3) & $98 \pm 2$ & $12 \pm 5$ & $10 \pm 7$ \\
\hline & Guanosine (5) & $88 \pm 4$ & $65 \pm 7$ & $51 \pm 10$ \\
\hline & Hypoxanthine plus & & & \\
\hline & guanosine (3) & $81 \pm 10$ & $6 \pm 4$ & $4 \pm 2$ \\
\hline \multirow[t]{4}{*}{ CFI } & None (4) & $92 \pm 4$ & $67 \pm 3$ & $58 \pm 2$ \\
\hline & Hypoxanthine (2) & $93 \pm 8$ & 0 & 0 \\
\hline & Adenosine (2) & $88 \pm 6$ & $8 \pm 1$ & 0 \\
\hline & Inosine (4) & $94 \pm 3$ & $3 \pm 3$ & 0 \\
\hline
\end{tabular}

$\dagger$ Number in parentheses is number of replicates as described in Table 1 .

$\ddagger$ As described in Table 1 . 
Most of the embryos that developed to morulae also developed to blastocysts, indicating that hypoxanthine has little or no effect on the morula/blastocyst transition. This was also true of morulae from DBA females which did not develop to blastocysts in $96 \mathrm{~h}$ with or without purine, but did so by $120 \mathrm{~h}$, in keeping with earlier observations (Biggers, 1971).

\section{Other purines and embryo development}

The addition of $30 \mu \mathrm{M}$-inosine or adenosine to the culture medium also inhibited development of zygotes from CDI and CF1 females (Table 2). The inhibition was not significantly different $(P>0.05)$ from that observed in the presence of hypoxanthine. On the other hand, guanosine $(30 \mu \mathrm{M})$, did not significantly $(P>0.05)$ inhibit development to the morula or blastocyst stage, nor did it reverse the hypoxanthine block.

The inhibition of embryonic development by hypoxanthine, adenosine and inosine was studied over a wide range of concentration. Figure 2 shows that inhibition at $3.0 \mu \mathrm{M}$ was similar to that obtained at $30 \mu \mathrm{M}$ in all three purines studied. However, at $0.3 \mu \mathrm{M}$, inosine had no inhibitory effect on development of pronuclear embryos to morulae, whereas both adenosine and hypoxanthine had a significant inhibitory effect at this concentration.

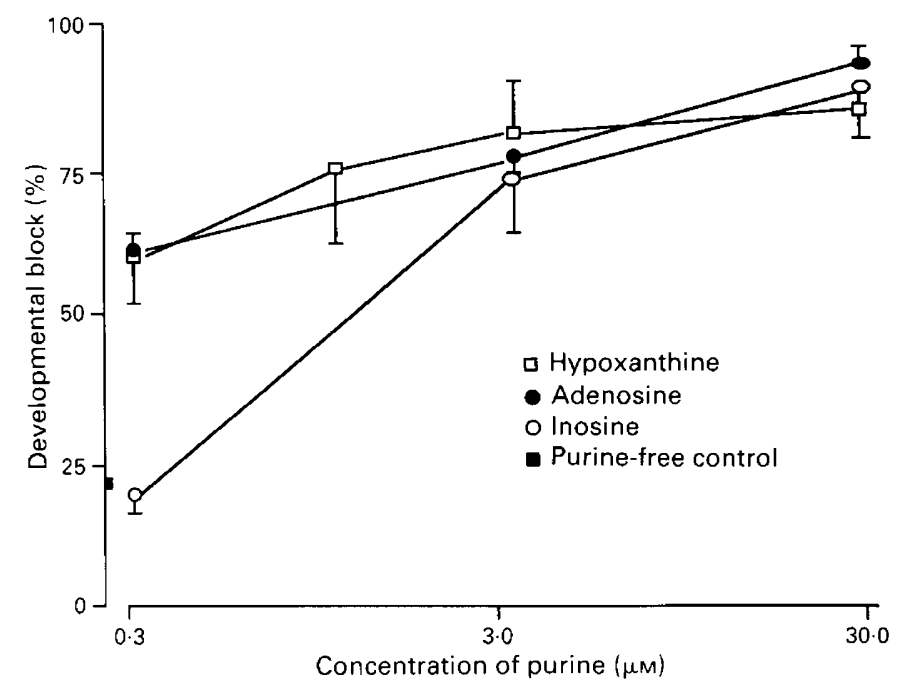

Fig. 2. Developmental arrest of mouse embryos at the 2- to 4-cell stage as a function of purine concentration.

\section{Effect of phosphodiesterase inhibitors on embryo development}

CD-1 pronuclear embryos were cultured in the presence of the phosphodiesterase inhibitors, theophylline and 1-methyl-3-isobutyl xanthine (IBMX), at $30 \mu \mathrm{M}$ each. These concentrations were the same as hypoxanthine and sufficient to inhibit the resumption of meiosis as measured by germinal vesicle breakdown (GVBD). No inhibition of morula development was observed for either compound (Table 3). Since inhibition of phosphodiesterase would lead to elevated intracellular amounts of cAMP, we included the membrane-permeable analogue, dibutyryl cAMP (100 $\mu \mathrm{M})$ as a control in these studies, and it also did not significantly $(P>0.05)$ inhibit cleavage. In contrast, GVBD was inhibited in the oocyte controls incubated in parallel in the dibutyryl cAMP and IBMX, but was not inhibited by $30 \mu \mathrm{M}$-hypoxanthine (Table 3 ). 
Table 3. Comparison of the effects of phosphodiesterase inhibitors on embryos and oocytes from CD1 females

\begin{tabular}{lccc}
\hline & \multicolumn{2}{c}{ Development +} & \\
\cline { 2 - 3 } Addition $\dagger$ & Two-cell & Morulae & $\begin{array}{c}\text { Oocyte } \\
\text { meiosis§ }\end{array}$ \\
\hline None (4) & $90 \pm 4$ & $91 \pm 1$ & 91 \\
Hypoxanthine (4) & $90 \pm 4$ & $17 \pm 4$ & 100 \\
IBMX (4) & $79 \pm 6$ & $93 \pm 7$ & 9 \\
dbcAMP (4) & $81 \pm 8$ & $77 \pm 8$ & 28 \\
Theophylline (3) & $79 \pm 4$ & $83 \pm 9$ & n.d. \\
\hline
\end{tabular}

$\dagger$ Hypoxanthine, IBMX and theophylline were added at $30 \mu \mathrm{M} ; \mathrm{dbcAMP}$ was included at $100 \mu \mathrm{M}$. Numbers in parentheses are replicates, as described in Table 1.

$\ddagger$ Expressed as $\% \pm$ s.e. of the mean, as described in Table 1.

§Measured by noting breakdown (expressed as \%) of the germinal vesicles in oocytes cultured in groups of 20 as controls $($ n.d. $=$ not determined).

\section{Reversibility of purine effects on CD1 embryos}

To determine whether the purine inhibition was reversible, zygotes were cultured in purinecontaining medium for $24 \mathrm{~h}$, approximately $6 \mathrm{~h}$ beyond the period of sensitivity. The resulting embryos were transferred to purine-free culture conditions, and development to morulae and blastocysts scored at $72 \mathrm{~h}$ after transfer (Table 4). The CDI pronuclear embryos exposed for $24 \mathrm{~h}$ to hypoxanthine, adenosine, or inosine, respectively, subsequently developed to blastocysts after transfer to purine-free medium, indicating that under these conditions the inhibitory effects of these purines are reversible.

Table 4. Reversibility of the purine block to CD-1 embryos

\begin{tabular}{lcccc}
\hline & \multicolumn{4}{c}{ Development* } \\
\cline { 2 - 5 } & \multicolumn{2}{c}{ Not transferred } & Transferred \\
\cline { 2 - 5 } Addition & Two-cell & Morulae & Two-cell & Morulae \\
\hline None & 78 & $69(88 \%)$ & & \\
Hypoxanthine & 60 & $8(13 \%)$ & 56 & $44(79 \%)$ \\
Adenosine & 40 & $3(8 \%)$ & 40 & $23(58 \%)$ \\
Inosine & 42 & $5(12 \%)$ & 44 & $34(77 \%)$ \\
\hline
\end{tabular}

*Embryos were collected at late pronuclear stage; one group was cultured for $96 \mathrm{~h}$ in standard purine-free media; other groups were cultured in purine-containing medium (not transferred) and parallel groups (transferred) were cultured for $24 \mathrm{~h}$ in purine-containing medium, then transferred to purine-free medium and cultured for an additional $72 \mathrm{~h}$. Purines were added at $30 \mu \mathrm{M}$.

\section{Inhibitors of purine metabolic pathways and CD1 embryo development}

The lack of inhibition of cleavage by guanosine was in contrast to the guanosine arrest of meiosis (Downs et al., 1985). This prompted us to investigate further whether the hypoxanthine 
inhibition was related to elevated guanosine amounts. Bredinin (Sakaguchi et al., 1975) and mycophenolic acid (Franklin \& Cook, 1969), inhibitors of enzymes in the pathway IMP to GMP (Reaction 2, Fig. 1), were used to test this possibility. The addition of bredinin at a concentration as low as $0.5 \mu \mathrm{M}$ completely inhibited CD1 embryo cleavage with or without hypoxanthine. Mycophenolic acid at $1 \mu \mathrm{M}$ was less inhibitory $(64 \%$ of $\mathrm{CD} 1$ zygotes that cleaved to 2 cells progressed to morulae), but failed to reverse the hypoxanthine arrest. Alternatively, hypoxanthine could be converted to AMP via IMP (Fig. 1). To test this possibility, we attempted to block the conversion of IMP to AMP with the antibiotic hadacidin, an inhibitor of adenylate succinate synthetase (Shigeura \& Gordon, 1962). Hadacidin alone at $30 \mu \mathrm{M}$ did not block morulae formation $(56 \%)$ by 2 -cell CF1 embryos, or modify the hypoxanthine inhibition $(8 \%$ to morulae in the presence of hadacidin and hypoxanthine).

\section{DNA synthesis}

To determine whether the purine inhibition affected the DNA synthesis (S) phase of the cell cycle, embryos from CD1 females cultured with or without hypoxanthine were incubated with $\left[{ }^{3} \mathrm{H}\right]$ thymidine added at $30 \mathrm{~h}$ (late pronuclear stage) or $40 \mathrm{~h}$ (mid 2-cell stage) after hCG. The 2-cell embryos that cleaved in the presence or absence of hypoxanthine incorporated equally the radiolabelled thymidine that was added at the late pronuclear stage; similarly, the 4-cell embryos that cleaved with or without hypoxanthine also incorporated equally the thymidine added at the mid 2-cell stage. The purine-induced block is, therefore, inhibiting a process that follows the onset of DNA replication.

\section{Discussion}

The results described here confirm and extend previous studies of the hypoxanthine sensitivity of early 2-cell mouse embryos (Loutradis et al., 1987). The first cleavage of zygotes exposed to purines approximately $12 \mathrm{~h}$ after fertilization (22-24 h after hCG) was not inhibited in any of the strains examined. The sensitivity of subsequent cleavages was not restricted to random-bred embryos, but was also observed in some inbred and hybrid-inbred strains of mice. The developmental arrest was most often at the 2-cell stage, although some embryos progressed to the 4-cell stage. This pattern of developmental blockage is similar to that reported for the 'two-cell block' (Goddard \& Pratt, 1983). The period of hypoxanthine sensitivity up to at least $40 \mathrm{~h}$ after hCG (Loutradis et al., 1987) is similar, although possibly somewhat prolonged relative to the period of 'two cell block' sensitivity (32 h after hCG: Goddard \& Pratt, 1983).

In keeping with our earlier findings, the paternal component of the zygote did not influence the hypoxanthine sensitivity of the embryos since all females were mated with hybrid-inbred males (B6D2F1). Embryos from C57BL/6 mothers were the most resistant of the inbred strains to hypoxanthine inhibition, followed by embryos from DBA mothers. Embryos from F-1 hybrids of C57BL/6 (B6D2Fl and B6SJL) were relatively unaffected by hypoxanthine, whereas those derived from the F1 hybrid of DBA (C3D2F1) were sensitive. Thus, resistance to hypoxanthine was best conferred by the $\mathrm{C} 57 \mathrm{BL} / 6$ mother. The purine sensitivity of embryos derived from several different strains lead us to believe that this phenomenon is targeting a process that plays an important role in early embryonic cleavage.

The hypoxanthine-induced block to meiosis has been suggested as being due to inhibition of phosphodiesterase activity with consequent increases in oocyte cAMP (Downs et al., 1989). However, in our studies, neither dibutyryl cAMP nor the phosphodiesterase inhibitors, theophylline and IBMX, caused a block to cleavage at concentrations that prevented the resumption of meiosis in oocytes. Moreover, concentrations of hypoxanthine that blocked embryonic cleavage were not effective in maintaining oocyte meiosis arrest. This is consistent with the observation that 
hypoxanthine is two orders of magnitude less effective than IBMX in inhibiting oocyte phosphodiesterase (Downs et al., 1989). These results show that the cleavage arrest by hypoxanthine is apparently not due to inhibition of phosphodiesterase activity in the early embryos.

We did not investigate higher concentrations of CAMP or IBMX since elevations in cAMP do lead to cleavage arrest. Ten-fold higher concentrations of dibutyryl cAMP and IBMX than we used in these studies resulted in a reversible block to the first cleavage if added during the G1 phase ( $18 \mathrm{~h}$ after hCG) of the cell cycle (Poueymirou \& Schultz, 1987). The resulting arrest was accompanied by changes in the patterns of protein phosphorylation that occur during the first cell cycle (Howlett, 1986), as well as an inhibition of synthesis of a set of proteins whose messenger RNAs are transcribed during the G1 phase of the second cell cycle (Poueymirou \& Schultz, 1987). A similar arrest of cleavage following exposure of embryos to X-irradiation $17-24 \mathrm{~h}$ after hCG was also accompanied by an inhibition of phosphorylation of this group of proteins (Grinfeld et al., 1987, 1988). To determine whether purines may similarly affect proteins during the first cleavage, we are currently investigating the effects of hypoxanthine exposure during the Gl phase of the zygote.

We found that similar concentrations of adenosine and inosine, but not guanosine, blocked embryonic development. However, at $0.3 \mu \mathrm{M}$, only hypoxanthine and adenosine, but not inosine, were effective. This suggests that either the purines have differential permeability through the cell membrane or that the inhibition is mediated by pathways other than through the conversion of adenosine and hypoxanthine to inosine. Analyses of the possible pathways of hypoxanthine inhibition of oocyte meiosis revealed that the inhibitors of IMP dehydrogenase, mycophenolic acid $(10 \mu \mathrm{M})$ and bredinin $(100 \mu \mathrm{M})$, effectively reversed the block to germinal vesicle breakdown. In vitro, mycophenolic acid was 10 -fold more effective than bredinin in overcoming the block to meiosis but, in vivo, bredinin was more effective (Downs et al., 1986; Downs \& Eppig, 1987). Our attempts to investigate similarly some of the purine pathways involved in the embryonic inhibition revealed no reversal of the arrest induced by hypoxanthine at concentrations of mycophenolic acid that did not inhibit cleavage (Hoshi et al., 1988). For reasons unknown, early embryonic cleavages were at least an order of magnitude more sensitive to bredinin, and 3 orders of magnitude more sensitive than germinal vesicle breakdown.

Our results therefore show that the purine-induced cleavage arrest differs from the purine inhibition of meiosis in several respects: first, guanosine is at least as effective as hypoxanthine in blocking GVBD but does not inhibit embryonic cleavage; second, phosphodiesterase inhibitors do not inhibit embryonic cleavage under conditions in which they inhibit GVBD; and third, the hypoxanthine arrest of GVBD, but not the arrest of cleavage, was reversed in the presence of the inhibitors of IMP dehydrogenase. Thus, the mechanisms involved in meiosis arrest (Cho et al., 1974; Wasserman et al., 1976; Bornslaeger et al., 1984; Downs et al., 1989) are apparently different from those involved in the purine-induced arrest of embryo cleavage.

The regulation of purine nucleotide metabolism in mouse embryos has not been well described. The enzyme hypoxanthine guanosine phosphoribosyl transferase, (HGPRT, Reaction 3, Fig. 1), which converts hypoxanthine to IMP and thus limits the conversion of hypoxanthine to uric acid, has been studied (Epstein, 1970). The activity of this enzyme is low at the pronuclear and 2-cell stages but increases steadily with subsequent cleavages to blastocyst formation. Paynton et al. (1988) detected maternal polyadenylated HGPRT mRNA in mature oocytes and show that this message is persistent to the late 2-cell stage, implying that the enzyme is probably translated from maternal message. The low level of activity of HGPRT at these early stages suggests that the conversion of hypoxanthine to IMP is probably limited.

The conversion of IMP to AMP or GMP at different stages of embryonic development has not been well investigated. Our attempt to investigate these two pathways in the hypoxanthine-blocked embryos by the use of inhibitors of IMP-dehydrogenase and adenylosuccinate synthetase (Fig. 1) revealed that bredinin completely blocked morula formation at concentrations as low as $0.5 \mu \mathrm{M}$. This suggests not only that the IMP to GMP pathway is important to early embryonic cleavage, but also that the embryos have an active adenine kinase, an enzyme reported to be responsible for 
converting bredinin to an active inhibitor of IMP dehydrogenase (Koyama \& Tsuji, 1983). Studies are in progress to measure the effectiveness of guanosine in reversing the bredinin toxicity. Adenosine also blocked embryonic development, although hadacidin failed to reverse the hypoxanthine block and did not inhibit cleavage at the same concentration as hypoxanthine. These results taken together indicate that the metabolic conversions of IMP to AMP or GMP do not play a significant role in the purine-induced block to development, although they may be essential cell processes in the early cleaving embryo.

As shown in Fig. 1, position 2 in the purine ring is unsubstituted in adenosine, inosine and hypoxanthine. However, the hydrogen atom at position 2 is substituted by an amino group in guanosine and by a carbonyl group in IMBX. These considerations suggest that the inhibition of cleavage beyond the 2-cell stage of hypoxanthine, adenosine and inosine may be due to steric inhibition of an enzyme reaction necessary for further embryonic development that a substitution at position 2 does not allow. Another possibility is interaction with adenosine receptors which have been described in many systems including brain, heart, adipocytes, and testis (Daly, 1985; Wolff et al. 1981). These receptors are located on the cell membrane, are bound to adenylate cyclase, and are classified relative to adenylate cyclase activity as stimulatory $\left(A_{2}\right.$ receptor) or inhibitory $\left(A_{1}\right.$ receptor). Salustri et al. (1988) have reported evidence of the $A_{2}$ receptor in mouse oocytes, but did not describe receptors in embryos. Our studies rule out elevation of cAMP as a principal cause of the purine-induced cleavage arrest, but do not address the possibility of decreases in cAMP (Boynton \& Whitfield, 1983).

Thymidine incorporation was not blocked in embryos cultured in hypoxanthine. Although the autoradiography studies do not confirm the completion of replication, the lack of inhibition of thymidine uptake suggests that the block to cleavage occurs after the onset of the $\mathrm{S}$ phase of the cycle. This is consistent with the cleavage arrest brought about by inhibition of cAMP-dependent protein kinase which also did not inhibit thymidine incorporation, although synthesis of the 'transcription requiring proteins', was inhibited (Poueymirou \& Schultz, 1989). We are currently investigating the effect of purines on the appearance of these proteins.

We thank Dr R. Fissore, R. Crowell and M. Kowal for helpful discussions and assistance during the course of the work which was supported in part by HD21890 (A.A.K.).

\section{References}

Biggers, J.D. (1971) New observations on the nutrition of the mammalian oocyte and the preimplantation embryo. In Blastocyst Biology, pp. 319-327. Ed. R. J. Blandau. Chicago University Press.

Bornslaeger, E.A., Wilde, M.W. \& Schultz, R.M. (1984) Regulation of mouse oocyte maturation: involvement of cyclic nucleotide phosphodiesterase and calmodulin. Devl Biol. 105, 488-499.

Boynton, A.L. \& Whitfield, J.F. (1983) The role of cyclic AMP in cell proliferation: a critical assessment of the evidence. Adv. cyclic Nucl. Res. 15, 193-294.

Chasin, M. \& Harris, D.N. (1976) Inhibitors and activators of cyclic nucleotide phosphodiesterase. Adv. cyclic Nucl. Res. 7, 225-252.

Cho, W.K., Stern, S. \& Biggers, J.D. (1974) Inhibitory effect of dibutyryl cAMP on mouse oocyte maturation in vitro. $J$. exp. Zool. 187, 383-386.

Clark, H.J. \& Masui, Y. (1983) The induction of reversible and irreversible chromosome decondensation by protein synthesis inhibition during meiotic maturation of mouse oocytes. Devl Biol. 97, 291-301.

Daly, J.W. (1985) Adenosine receptors. Adv. cyclic Nucl. Protein Phos. Res. 19, 29-46.
Downs, S.M. \& Eppig, J.J. (1987) Induction of mouse oocyte maturation in vivo by perturbants of purine metabolism. Biol. Reprod. 36, 431-437.

Downs, S.M., Coleman, D.L., Ward-Bailey, P.F. \& Eppig, J.J. (1985) Hypoxanthine is the principal inhibitor of murine oocyte maturation in a low molecular weight fraction of purine follicular fluid. Proc.natn. Acad. Sci. USA 82, 424-458.

Downs, S.M., Coleman, D.L. \& Eppig, J.J. (1986) Maintenance of murine oocyte meiotic arrest: uptake and metabolism of hypoxanthine and adenosine by cumulus cell-enclosed and denuded oocytes. Devl Biol. 117, 174-183.

Downs, S.M., Daniel, S.A.J., Bornslaeger, E.A., Hoppe, P.C. \& Eppig, J.J. (1989) Maintenance of meiotic arrest in mouse oocytes by purines: modulation of cAMP levels and cAMP phosphodiesterase activity. Gamete Res. 23, 323-334.

Eppig, J.J. \& Downs, S.M. (1987) The effect of hypoxanthine on mouse oocyte growth and development in vitro: maintenance of meiotic arrest and gonadotropin-induced oocyte maturation. Devl Biol. 119, 313-321. 
Epstein, C.J. (1970) Phosphoribosyltransferase activity during early mammalian development. J. biol. Chem. 245, 3280-3294.

Fissore, R.A., Jackson, K.V. \& Kiessling, A.A. (1989) Mouse zygote development in culture medium without protein in the presence of ethylenediamine tetraacetic acid. Biol. Reprod. 41, 835-841.

Franklin, T.J. \& Cook, J.M. (1969) The inhibition of nucleic acid synthesis by micophenolic acid. Biochem. $J .113,515-524$.

Goddard, M.J. \& Pratt, H.P.M. (1983) Control of events during early cleavage of the mouse embryo: an analysis of the '2-cell block'. J. Embryol. exp. Morph. 73, $111-133$.

Grinfeld, S., Gilles, J., Jacquet, P. \& Baugnet-Mahieu, L. (1987) Late division kinetics in relation to modification of protein synthesis in mouse eggs blocked in the $\mathrm{G}_{2}$ phase after $\mathrm{X}$-irradiation. Int. J. Radiat. Biol. 52, 77-86.

Grinfeld, S., Jacquet, P., Gilles, J. \& Baugnet-Mahieu, L. (1988) The X-ray induced $G_{2}$ arrest in mouse eggs: a maternal effect involving a lack of polypeptide phosphorylation. Roux's Arch. Dev. Biol. 197, 302-304.

Ham, R.G. (1962) An improved nutrient solution for diploid chinese hamster and human cell lines. Expl Cell Res. 29, 515-526.

Hoshi, M., Mizuno, A. \& Yuki, A. (1988) Restoration by xanthine of development of mouse embryos inhibited by mycophenolic acid. J. Reprod. Fert. 83, 85-89.

Howlett, S.K. (1986) A set of proteins showing cell cycle dependent modification in the early mouse embryo. Cell 45, 387-396.

Jackson, K.V. \& Kiessling, A.A. (1989) Fertilization of mouse oocytes exposed to the conditions of human oocyte retrieval for in vitro fertilization. Fert. Steril. $51,1-7$.

Koyama, H. \& Tsuji, M. (1983) Genetic and biochemical studies on the activation and cytotoxic mechanism of bredinin, a potent inhibitor of purine biosynthesis in mammalian cells. Biochem. Pharmacol. 32, 3547-3553.

Loutradis, D., John, D. \& Kiessling, A.A. (1987) Hypoxanthine causes a 2 -cell block in random-bred mouse embryos. Biol. Reprod. 37, 311-316.
Muggleton-Harris, A., Whittingham, D.G. \& Wilson, L. (1982) Cytoplasmic control of preimplantation development in vitro in the mouse. Nature, Lond. 299, $460-462$.

Paynton, B.V., Rempel, R. \& Bachvarova, R. (1988) Changes in state of adenylation and time course of degradation of maternal mRNA's during oocyte maturation and early embryonic development in the mouse. Devl Biol. 129, 304-314.

Poueymirou, W.T. \& Schultz, R.M. (1987) Differential effects of activators of cAMP-dependent protein kinase and protein kinase $\mathrm{C}$ on cleavage of one-cell mouse embryos and protein synthesis and phosphorylation in one- and two-cell embryos. Devl Biol. 121, 489-498.

Poueymirou, W.T. \& Schultz, R.M. (1989) Regulation of mouse preimplantation development: inhibition of synthesis of proteins in two-cell embryos that require transcription by inhibitors of cAMP-dependent protein kinase. Devl Biol. 133, 588-599.

Pratt, H.P.M. \& Muggleton-Harris, A.L. (1988) Cyclic cytoplasmic factors that promote mitosis in the cultured 2-cell mouse embryo. Development 104, 115-120.

Sakaguchi, K., Tsujino, M., Yoshizawa, M., Mizuno, K., \& Hayano, K. (1975) Action of bredinin on mammalian cells. Cancer Res. 35, 1643-1647.

Salustri, A., Petrungaro, S., Conti, M. \& Siracusa, G. (1988) Adenosine potentiates Forskolin-induced delay of meiotic resumption by denuded oocytes: Evidence of an oocyte surface site of adenosine action. Gamete Res. 21, 157-168.

Shigeura, H.T. \& Gordon, C.N. (1962) The mechanism of action of hadacidin. J. biol. Chem. 237, 1937-1940.

Wasserman, P.M., Josefowicz, W.J. \& Letourneau, G.E. (1976) Meiotic maturation of mouse oocytes in vitro: inhibition of maturation at specific stages of nuclear progression. J. Cell Sci. 22, $531-539$.

Wolf, J., Londons, C. \& Cooper, D.M.F. (1981) Adenosine receptors and the regulation of adenylate cyclase. $A d v$. cyclic Nucl. Res. 14, 199-214.

Received 5 February 1990 